\title{
Wilhelm II a kwestia przystąpienia Bułgarii do pierwszej wojny światowej. Kilka uwag na marginesie książki P. Szlan- ty Wilhelm II. Ostatni z Hohenzollernów, Książka i Wiedza, Warszawa 2015, ss. 376
}

\section{STRESZCZENIE:}

Ostatni cesarz Niemiec Wilhelm II Hohenzollern należy do grona postaci, które budziły i nadal budzą żywe zainteresowanie historyków. Będąc jednym z najbardziej wpływowych władców swoich czasów odcisnął on silne piętno na polityce światowej. Dzięki jego postawie podczas pierwszej wojny światowej Bułgaria związała swoje losy z Niemcami. Kwestia ta latem 1915 r. była jednym z priorytetów niemieckiej polityki zagranicznej, w której aktywny udział brał władca Niemiec. światowa

Słowa kluczowe: Wilhelm II Hohenzollern, Niemcy, Bułgaria, pierwsza wojna

W 2015 r. na rynku księgarskim ukazała się praca przedstawiająca biografię ostatniego cesarza Niemiec i króla Prus Wilhelma II Hohenzollerna autorstwa Piotra Szlanty. Badacz ten od wielu lat zajmuje się historią stosunków międzynarodowych i dziejami Niemiec w XIX w., kulturą polityczną przełomu XIX i XX w., kolonializmem, relacjami polsko-niemieckimi oraz pierwszą wojną światową ${ }^{1}$ Ta prezentacja jego szerokich zainteresowań badawczych i dotychczasowy dorobek zamykający się liczbą ponad stu artykułów naukowych i popularnonaukowych oraz kilkoma monografiami i podręcznikami szkolnymi może stanowić rękojmię, że recenzowana książka stanowi dobrze przygotowaną i udokumentowaną pracę.

${ }^{1}$ Zob. biogram Autora zamieszczony na okładce recenzowanego opracowania jak również widniejący na stronie internetowej Instytutu Historycznego Uniwersytetu Warszawskiego: www.ihuw.pl/instytut/o-instytucie/pracownicy/dr-piotr-szlanta (dostęp 2 IX 2015 r.). 
Opracowana przez P. Szlantę biografia składa się ze wstępu, dziewięciu rozdziałów, zakończenia, bibliografii i indeksu osobowego. $\mathrm{W}$ pracy znajduje się również 46 ilustracji przedstawiających głównego bohatera na różnych etapach jego życia oraz osoby mu współczesne.

Całość materiału ma układ chronologiczno-problemowy. W pierwszych ośmiu rozdziałach opisane są losy Wilhelma II od momentu narodzenia, poprzez dzieciństwo, wiek dojrzały aż do chwili śmierci w $1941 \mathrm{r}$. Ostatni, dziewiąty rozdział poświęcony został problematyce polskiej i został zatytułowany Wilhelm II wobec Polaków. Wyodrębnienie kwestii polskiej w oddzielnym rozdziale należy uznać za niezwykle fortunne i ciekawe rozwiązanie. Pozwala ono polskiemu czytelnikowi na zapoznanie się w sposób uporządkowany z poglądami ostatniego władcy z rodu Hohenzollernów na temat sprawy polskiej i samych Polaków. Jednocześnie nie zaburza to głównego toku narracji poprzez nadmierne wyeksponowanie wątków w dużej mierze drugorzędnych z punktu widzenia polityki niemieckiej, która to przypadłość jest typowa dla polskich autorów piszących o XIX-wiecznych Niemczech.

Omawiając zawartość książki, podkreślić należy jej bogatą bazę źródłową na którą składają się: wydawnictwa źródłowe, listy, pamiętniki, prasa i współczesne opracowania. W przytłaczającej większości wyszły one spod rąk autorów obcojęzycznych, wśród których z oczywistych względów dominują badacze niemieccy. W bibliografii wymienione zostały także archiwalia. Biorąc jednak pod uwagę treść przypisów, występują one w stosunkowo niewielkiej liczbie i są obecne głównie w ostatnim rozdziale, poświęconym problematyce polskiej.

Ważna rola Wilhelma II w historii Niemiec i Europy, na co zwrócono uwagę we wstępie (s. 11), jest niepodważalna. Wywarł on także duży wpływ na historię Polski. Dziwić może zatem fakt, że w naszym kraju do tej pory nie było biografii niemieckiego władcy napisanej przez polskiego badacza. Na rynku wydawniczym, nie licząc czterech (o mocno ograniczonej wartości naukowej) pozycji książkowych wydanych jeszcze w okresie międzywojennym² ${ }^{2}$ ukazały się wyłącznie tłumaczenia niemieckich autorów o charakterze popularnonaukowym ${ }^{3}$. Dlatego też z satys-

${ }^{2}$ A. Podwojski, Kaiser Wilhelm II, Warszawa 1919; A. Nowaczyński, Wilhelm Imperator 1888-1918, 9 listopada, Katowice 1928; M. Oskierko, Wilhelm II. Awanturniczy Kaiser, Warszawa 1932.

${ }^{3}$ E. Ludwig, Wilhelm II, tłum. J. Zylberowa, Warszawa 1930; E. Hartau, Wilhelm II, tłum. A. Marcinek, Lublin 1995; T. Aronson, Cesarze niemieccy 1871-1918, tłum. M. Czarnecka, Kraków 1998; idem, Zwaśnieni monarchowie. Europejskie trony w przededniu katastrofy 1914 roku, przekł. A. Glondys, Kraków 2014 (wyd. II); M. Schad, Hohenzollernowie, tłum. M. Urbański, Warszawa 2004; C. Clay, Król, cesarz, car, tłum. G. Waluga, Warszawa 2007. 
fakcją należy odnotować wydanie biografii autorstwa P. Szlanty, która jest pod tym względem pracą pionierską.

Ten fakt wcale nie ułatwił jednak zadania dokonującemu owej pracy. P. Szlanta musiał wyszukać i wybrać spośród całej plejady prac te najbardziej wartościowe, które posłużyły mu następnie do skonstruowania narracji. Wysiłek ów, co trzeba od razu stwierdzić, zakończył się pełnym powodzeniem. Na podkreślenie zasługuje przy tym fakt, że P. Szlanta starał się zachować bezstronny osąd Wilhelma II, unikając z jednej strony nadmiernej sympatii do opisywanej postaci, z drugiej zaś uproszczonych osądów przedstawiających go wyłącznie w czarnych barwach. Ciekawym poznawczo zabiegiem było wyeksponowanie czynników, które miały kluczowy wpływ na formowanie się poglądów przyszłego władcy Niemiec, przy słusznym założeniu, że warunki i atmosfera rodzinna w dużym stopniu ukształtowały jego osobowość.

Przedmiotem uwag nie będą jednak perypetie rodzinne Wilhelma II ani też kwestie związane z jego stosunkiem do Polski i Polaków. W recenzji chciałbym zająć się nieco szerzej kwestią bułgarska, a konkretnie przyjrzeć się okolicznościom, które doprowadziły do przyłączenia się tego kraju do pierwszej wojny światowej po stronie Niemiec. Problematyka ta jest niezwykle rzadko poruszana $\mathrm{w}$ polskim piśmiennictwie, stąd też setna rocznica tego wydarzenia, która przypadła w roku 2015, jest doskonałym pretekstem do zajęcia się nią.

P. Szlanta opisując różne aspekty polityki zagranicznej współtworzonej przez cesarza Niemiec, kilkakrotnie podejmuje kwestie bułgarskie. Są to głównie informacje o relacjach łączących Wilhelma $\mathrm{z}$ wywodzącymi się z niemieckiego kręgu kulturowego bułgarskimi władcami. Po raz pierwszy biograf podjął ten temat na s. 24, przedstawiając negatywne stanowisko młodego Wilhelma do pomysłu zaślubin jego siostry z księciem Bułgarii Aleksandrem I von Battenbergiem, co wynikało z żywionych przez niego obaw przed obniżeniem autorytetu rodziny w Europie. Ciekawostką jest przy tym fakt, że bułgarski władca był siostrzeńcem carowej rosyjskiej i synem austriackiego generała ks. Aleksandra Ludwika von HessenDarmstadt z morganatycznej małżonki hr. Julii Teresy Hauke, córki generała artylerii Wojska Polskiego i ministra wojny Królestwa Polskiego Jana Maurycego Hauke herbu Bosak. Domieszka polskiej krwi, jak się wydaje, nie miała większego znaczenia, lecz mimo to nieprzychylni mu politycy (w tym Bismarck) doszukiwali się $\mathrm{w}$ jego zachowaniu oznak polskości ${ }^{4}$. Niedoszły szwagier nie mógł liczyć także na wsparcie ze strony Wilhelma w momencie wybuchu w 1885 r. kryzysu rosyjsko-bułgarskiego, który

${ }^{4}$ Z. Klejn, Bułgaria: szkice z dziejów najnowszych, Pułtusk 2005, s. 22. 
ostatecznie doprowadził do jego abdykacji. W tym przypadku przyszły Kajzer przedkładał wyżej podtrzymanie dobrych stosunków z Rosją niż zachowanie przy władzy księcia (s. 28).

Chłodne stosunki łączyły Wilhelma również z następcą Aleksandra I, księciem Ferdynandem Maksymilianem Karlem Leopoldem Marią von Sachsen-Coburg-Gotha, który jako władca Bułgarii przyjął imię Ferdynanda I. Mimo silnych związków łączących go z prawie wszystkimi domami panującymi w Europie nie należał on do osób poważanych przez Wilhelma (s. 37). Bułgarski władca, co warto przypomnieć, ze strony ojca był skoligacony z królową Wiktorią i jej małżonkiem księciem Albertem Franzem Augustem Carlem Emmanuelem Sachsen-Coburg-Gotha, księciem Wielkiej Brytanii i Irlandii. Ze strony matki był natomiast wnukiem ostatniego monarchy Francji wywodzącego się z rodu Burbonów - Ludwika Filipa I. Koneksje rodzinne oraz poparcie ze strony dworu w Wiedniu i Londynie w niczym nie pomogły bułgarskiemu władcy, do którego cesarz Niemiec odnosił się z lekceważeniem. Obcesowe zachowanie Kajzera było wynikiem, co podkreśla P. Szlanta, jego ekscentrycznego charakteru (s. 76) i występowało również w stosunku do innych członków rodzin panujących. Relacje między obu władcami wynikały - jak należy sądzić także z cech charakterologicznych Ferdynanda I, który był postrzegany na dworach europejskich jako władca często zmieniający zdanie (nadmiernie pragmatyczny?), przez co jego adwersarze nadali mu przydomek Lis albo Bałkański Lis. Określenia te miały podkreślać jego spryt, zaradność, a niekiedy nawet perfidię działania ${ }^{5}$.

Stosunki niemiecko-bułgarskie nie były wyłącznie pochodną układów towarzyskich pomiędzy władcami i ulegały daleko idącym przeobrażeniom. Wynikało to ze stopniowo rosnącego zainteresowania kwestią wschodnią przez kręgi rządzące $w$ Niemczech oraz umacniania się pozycji Bułgarii w rejonie basenu Morza Czarnego. Na podstawie książki można natomiast odnieść mylne wrażenie, że relacje niemiecko-bułgarskie sprowadzały się głównie do kwestii dynastycznych, czego nie tłumaczy przecież skupienie się przez P. Szlantę przede wszystkim na osobie Kajzera. Jako głowa państwa współtworzył on bowiem politykę zagraniczną Niemiec, która dalece wykraczała poza stosunki łączące poszczególne dwory europejskie.

Widocznym przejawem wzrostu znaczenia Bułgarii na Bałkanach było w 1908 r. zerwanie zależności od Imperium Osmańskiego, proklamowanie niepodległości i przyjęcie tytułu cara przez księcia Ferdynanda I,

${ }^{5}$ Szerzej na ten temat np. S. Constant, Foxy Ferdinand, 1861-1948. Tsar of Bulgaria, London 1979. 
co spotkało się z chłodnym przyjęciem w Berlinie (s. 214). Bułgaria, mimo dzielących ją różnic z sąsiadami, potrafiła także, przy wydatnej pomocy dyplomacji rosyjskiej, porozumieć się z Grecją i Serbią oraz zawiązać koalicję państw bałkańskich przeciwko Imperium Osmańskiemu, która odniosła zwycięstwo w wojnie przeciwko armii sułtana (pierwsza wojna bałkańska 1912-1913). Spory o podział zdobytych ziem doprowadziły jednak do wybuchu nowej wojny (druga wojna bałkańska 1913 r.), tym razem pomiędzy członkami zwycięskiej koalicji. Zakończyła się ona klęską osamotnionej Bułgarii. Odtąd długofalowym celem jej polityki zagranicznej była zemsta za doznane upokorzenie w roku 1913 i odwet na Serbii oraz Grecji6.

Aby to osiagnąć, pozostający pod silnym wpływem monarchy rząd Bułgarii obrał kurs na zbliżenie z Państwami Centralnymi. Początkowo spotkało się to $\mathrm{z}$ pewną powściągliwością ze strony jego obu partnerów, jako że Austro-Węgry i Niemcy nie chciały wiązać się z Bułgarią, aby nie zrazić do siebie Rumunii i Grecji. W obu tych państwach rządzili władcy pochodzenia niemieckiego, silnie związani z dworem w Berlinie. W Rumunii na tronie zasiadał Karol I z dynastii Hohenzollern-Sigmaringen, katolickiej gałęzi rodu Hohenzollernów, zaś w Grecji Konstantyn I z dynastii Glücksburgów, żonaty z siostrą Wilhelma II, księżną Zofią Dorotą Ulryką. Ponadto w Berlinie i Wiedniu odnoszono się z lekceważeniem do możliwości wojskowych Bułgarii, dając pierwszeństwo Rumunii, z którą oba państwa łączyło tajne porozumienie obronne, zawarte jeszcze w $1883 r^{7}$

Stosunek Niemiec do Bułgarii w tym okresie najlepiej wyraża tajna instrukcja w sprawie kierunków polityki zagranicznej na Bałkanach z 16 sierpnia 1913 r. W dokumencie tym cesarz Niemiec Wilhelm II do potencjalnych sojuszników zaliczył Rumunię, Turcję i Grecję. Serbia i Czarnogóra, pozostające $\mathrm{w}$ sojuszu z Rosją zostały uznane za państwa wrogie, a Bułgaria w tym zestawieniu występuje jako kraj nieokreślony ${ }^{8}$.

Przełom w podejściu do Bułgarii nastąpił $\mathrm{z}$ chwilą podjęcia przez rząd w Sofii starań o przyznanie kredytów potrzebnych do spłaty odszkodowań wojennych i zwrotu krótkotrwałych pożyczek zaciągniętych w Paryżu i Petersburgu. Banki francuskie, które były tradycyjnym partnerem finansowym Bułgarii, pod wpływem rosyjskiej dyplomacji uzależniły

${ }^{6}$ M. Pissari, Bulgarian Crimes against Civilians in Occupied Serbia during the First World War, „Balcanica” 2013, t. 44, s. 371.

${ }^{7} \mathrm{Na}$ ten temat: H. Wereszycki, Koniec sojuszu trzech cesarzy, t. III, Warszawa 2010 (wyd. II), s. 218-226.

${ }^{8}$ Û.A. Pisarev, Velikie deržavy i Balkany nakanune pervoj mirovoj vojny, Moskva 1985, s. 207. 
udzielenie pożyczki od spełnienia określonych warunków politycznych, w tym zmiany proniemieckiego rządu kierowanego przez dr. Wasila Radosławowa9.

W tej sytuacji, nie chcąc godzić się na ów dyktat, na początku $1914 \mathrm{r}$. rząd bułgarski rozpoczął negocjacje z wielkim berlińskim konsorcjum bankowym Disconto-Gesellschaft. W grę wchodziła astronomiczna na ówczesne warunki kwota $500 \mathrm{mln}$ lewów. Bankierzy niemieccy żywili początkowo poważne obawy co do korzyści ekonomicznych płynących z faktu udzielenia takiej pożyczki, ale ustąpili pod presją swojego rzą$\mathrm{du}$, który działał $\mathrm{w}$ porozumieniu $\mathrm{z}$ Wilhelmem II. Ostatecznie, zgodnie $\mathrm{z}$ wynegocjowanymi warunkami, pożyczka ta została przyznana ${ }^{10}$. Tym samym niemiecki imperializm wygrał walkę o wpływy w Bułgarii.

Rola Bułgarii wydatnie wzrosła w momencie wybuchu wojny ogólnoeuropejskiej. Niestety uwaga P. Szlanty w kontekście nowych wydarzeń została skupiona przede wszystkim na funkcji, jaką odgrywał cesarz w polityce wewnętrznej Niemiec. Takie rozłożenie akcentów jest do pewnego stopnia zrozumiałe, gdyż praca nie miała na celu opisywanie przecież przebiegu Wielkiej Wojny, a jedynie aktywność Wilhelma II w latach 1914-1918. Rzecz jednak w tym, że wciągnięcie Bułgarii do wojny $\mathrm{w}$ pewnym momencie stało się jednym z priorytetów $\mathrm{w}$ polityce zagranicznej Niemiec, zaś Kajzer - pomimo odsunięcia go od spraw wojskowych (s. 249) - wciąż zachowywał wpływ na działania niemieckiej dyplomacji.

Zainteresowanie Bułgarią wynikało z jej położenia w centrum Półwyspu Bałkańskiego, które przyciągało uwagę strategów wojskowych walczących koalicji. Dla państw Ententy bułgarski przyczółek miał pierwszorzędne znaczenie $\mathrm{w}$ rywalizacji o przejęcie kontroli nad cieśninami tureckimi. Ewentualna decyzja o związaniu się z Francja, Wielką Brytanią i Rosją mogłaby też być dobrym przykładem dla Grecji i Rumunii wciąż wahających się, po której stronie mają się opowiedzieć. Natomiast dla Niemiec i Austro-Węgier sojusz z Bułgarią nie tylko stwarzał warunki do utrzymania więzi z Imperium Osmańskim, z którym 2 sierpnia 1914 r. został zawarty tajny układ sojuszniczy, ale dodatkowo dawał nowe możliwości w przypadku ataku na Serbię. Według ówczesnych ekspertów wojskowych przystąpienie Bułgarii do wojny po stronie Państw Centralnych mogło znacznie skomplikować sytuację Ententy i przedłużyć wojnę nie tylko na Bałkanach, ale i w całej Europie. Nie bez znaczenia dla obu stron pozostawał również fakt, że Bułgaria była ważnym dostawcą pro-

${ }^{9}$ I. Ilčev, B"lgariâ $i$ Antantata prez p"rvata svetovna vojna, Sofiâ 1990, s. 47.

${ }^{10} \mathrm{C}$. Todorova, Istoriâ na v'nešniâ d"žaven d"lg na B"lgariâ (1878-1990 g.), t. I, Dramatično načalo (1878-1918), Sofiâ 2009, s. 173-174. 
duktów rolnych, żywności i materiałów strategicznych, a jej armia stanowiła, mimo odniesionej w $1913 \mathrm{r}$. klęski, liczącą się siłę w regionie ${ }^{11}$. Tym samym Bułgaria była kluczowym elementem planów strategicznych obu wojujących koalicji ${ }^{12}$.

W związku z rozpoczęciem działań wojennych w Europie Bułgaria oficjalnie zadeklarowała ścisłą neutralność i przyjęła postawę wyczekującą. Bułgarska deklaracja neutralności została odebrana przez wojujące państwa życzliwie, jako że członkowie obu koalicji przeświadczeni byli o swoim rychłym zwycięstwie. Wraz z upływem czasu i stopniowym wzrostem świadomości, że wojna może być długa, oba bloki przystąpiły do działań mających na celu przeciągnięcie Bułgarii na swoją stronę lub co najmniej uzyskanie z jej strony życzliwej neutralności. Głównym elementem przetargowym $\mathrm{w}$ prowadzonych rozmowach dyplomatycznych był obszar Macedonii, który w dużym stopniu zamieszkany był przez ludność pochodzenia bułgarskiego, a po drugiej wojnie bałkańskiej znalazł się we władaniu Serbii. Związki rodzinne Wilhelma II z carem Bułgarii czyniły z niego ważnego uczestnika negocjacji.

Ostatecznie to Państwa Centralne przedstawiły bardziej konkretną ofertę, co przesądziło o podjęciu decyzji w sprawie zawarcia sojuszu wojskowego z nimi. 6 września 1915 r. przedstawiciele rządu bułgarskiego i niemieckiego w osobach księcia Johanna Albrechta Meklemburskiego i dyrektora Departamentu Spraw Bałkańskich Ministerstwa Spraw Zagranicznych Niemiec podpisali tajną konwencję. Zgodnie z tym dokumentem Bułgaria za udział w "akcji wojennej przeciwko Serbii” miała otrzymać należącą do niej część Macedonii. Kolejny punkt porozumienia głosił, że w przypadku przyłączenia się do wojny Grecji i Rumunii po stronie państw Ententy Bułgarii przypadnie także grecka część Macedonii i Tracji oraz Dobrudża ${ }^{13}$.

W tym samym dniu w Kwaterze Głównej Naczelnego Dowództwa Armii Niemieckiej w zamku Pless (ob. Pszczyna) przedstawiciele armii niemieckiej, austriackiej i bułgarskiej podpisali konwencję wojskową. Przewidywała ona, że po upływie 30 dni od jej podpisania rozpoczną się działania zbrojne wojsk niemieckich i austriackich przeciwko Serbii. Pięć dni później do akcji miały przystąpić oddziały bułgarskie, przez co front ataku ulegał znacznemu rozszerzeniu na południe ${ }^{14}$.

\footnotetext{
${ }^{11}$ R. J. Crampton, Bulgaria, Oxford 2007, s. 206-207.

${ }^{12}$ U. Gotlib, B"lgariâ v meždunarodnata polityka (1914-1915), „Izvestiâ na Instituta za Istoriâ BAN" 1974, t. 23, s. 15-16.

${ }^{13}$ E. Statelova, S. Gr"nčarov, Istoriâ na nova B"lgariâ (1878-1944), t. III, Sofiâ 1999, s. 304.

${ }^{14}$ Ibidem.
} 
Ukoronowaniem zacieśniającej się na wszystkich szczeblach współpracy niemiecko-bułgarskiej było oficjalne podpisanie 17 września $1915 \mathrm{r}$. w Sofii traktatu o przyjaźni i sojuszu między obu państwami ${ }^{15}$.

Podpisane latem i jesienią 1915 r. porozumienia były wielkim sukcesem dyplomacji Niemiec i Austro-Węgier. W ich konsekwencji 14 października 1915 r. Bułgaria przystąpiła do wojny, dzięki czemu istniejące do tej pory Trójprzymierze przekształciło się w Czwórprzymierze.

Przedstawione powyżej kwestie zostały pominięte $\mathrm{w}$ omawianej biografii Wilhelma II, podobnie jak zabiegi zmierzające do skłonienia Imperium Osmańskiego do czynnego włączenia się do pierwszej wojny światowej. P. Szlanta nadmiernie skupił się na „wielkiej polityce”, nieco marginalizując te zagadnienia. Próżno szukać także wzmianek o roli, jaką cesarz starał się odgrywać w podtrzymaniu woli walki sojuszników Niemiec w czasie trwania wojny. Ogólnie należy wyrazić żal, że kwestia roli Wilhelma II w czasie Wielkiej Wojny została przedstawiona zbyt powierzchownie i poświęcono jej zaledwie 26 stron (s. 247-273), co w przypadku historyka zajmującego się problematyką pierwszej wojny światowej jest pewnym rozczarowaniem - nawet jeżeli rola Kajzera była w niektórych kwestiach wyłącznie fasadowa.

Książka P. Szlanty w części poświęconej zagadnieniom bałkańskim stanowi zatem odbicie szerszego zjawiska, typowego dla historiografii krajów zachodnich. Polega ono na nadmiernym skupieniu się na głównych frontach pierwszej wojny światowej kosztem tych mniej znanych, co nie oznacza, że mniej istotnych. Bułgaria, będąc państwem w największej mierze odpowiedzialnym za utrzymanie Frontu Macedońskiego, zabezpieczała południowo-wschodnie granice Państw Centralnych, co pomimo udziału wojsk niemieckich w walkach prowadzonych na Bałkanach pozwoliło niemieckiemu Sztabowi Generalnemu na skupienie sił na innych frontach ${ }^{16}$. Wciągnięcie Bułgarii do wojny było więc w pewnym momencie niezwykle istotnym zadaniem, którego realizacji musiała podołać dyplomacja niemiecka. Ponieważ Wilhelm II formalnie przez ten czas pozostawał głową państwa, a ponadto łączyły go związki rodzinne z carem Bułgarii, jego postępowanie miało istotny wpływ na powodzenie całego projektu. Nie ułatwiały tego specyficzne cechy monarchy i jego pogardli-

${ }^{15}$ Dogovor za priâtelstvo $i$ s"ûz meždu B"lgariâ $i$ Germanskata Imperiâ, Sofiâ, 4 septemvri 1915 g., dok. nr 33, [w:] B"lgarska vojenna istoriâ. Podbrani izvori i dokumenty, t. 3, red. H. Hristov, Sofiâ 1986, s. 62.

${ }^{16}$ A. A. Nofi, Comparative Divisional Strengths During World War I: East Central European Belligerents and Theaters, [w:] War and Society in East Central Europe, vol. 19: East Central European Society in World War I, eds. B. Király, N.F. Dreisziger, New York 1985, s. 268. 
wy stosunek do bułgarskiego władcy (s. 75-76), niemniej ostatecznie udało się tego dokonać.

Rzecz jasna nie można wymagać od biografa Wilhelma II szczegółowego opisu „kwestii bułgarskiej”, lecz jej zasygnalizowanie jawi się jako bezwzględnie konieczne. Można nawet odnieść wrażenie, że współcześni historycy mimowolnie przejmują punkt widzenia przedstawicieli niemieckich warstw wyższych, które odnosiły się do państw bałkańskich $\mathrm{z}$ nieukrywanym lekceważeniem, co przekładało się z kolei na obecność poświęconych im wątków w publikowanych po wojnie wspomnieniach. Nie dotyczyło to jednak kręgów wojskowych, które doskonale zdawały sobie sprawę ze znaczenia Bułgarii w pierwszej wojnie światowej, nawet jeśli poszczególni oficerowie wypowiadali się krytycznie na temat poszczególnych aspektów związanych z zaopatrzeniem armii bułgarskiej czy jej dowodzeniem ${ }^{17}$.

Niezależnie od przedstawionych uwag, trzeba przyznać, że omawiana książka jest interesującą pozycją, szczególnie jeśli chodzi o te fragmenty, które odnoszą się do warunków, w jakich wzrastał ostatni władca Niemiec, a które ukształtowały jego osobowość i światopogląd. Pozwala to bowiem lepiej zrozumieć jego późniejsze decyzje i przyświecające mu motywy działania. Szczególnie godny uwagi dla rodzimego czytelnika jest również mocno rozbudowany (50 stron) ostatni rozdział poświęcony sprawom polskim. Na zakończenie trzeba zaznaczyć, że książkę czyta się po prostu przyjemnie, zarówno z uwagi na jej stronę językowa, jak merytoryczną. Reasumując, z całą odpowiedzialnością można stwierdzić, że książka w znacznym stopniu przyczyni się do wzbogaceniu wiedzy polskich czytelników o ostatnim władcy Niemiec i czasach, w których żył, jak również wypełni istniejącą lukę na rynku wydawniczym. Szkoda tylko, że w niewielkim stopniu dotyczy to działań dyplomatycznych Wilhelma II dotyczących państw bałkańskich, gdyż kwestia ta - choć wciąż niedoceniana w światowej historiografii - mogła w pewnym momencie zaważyć na wyniku całej wojny.

\section{BIBLIOGRAFIA:}

Aronson T., Cesarze niemieccy 1871-1918, tłum. M. Czarnecka, Kraków 1998.

Aronson T., Zwaśnieni monarchowie. Europejskie trony w przededniu katastrofy 1914 roku, przekł. A. Glondys, Kraków 2014 (wyd. II).

Clay C., Król, cesarz, car, tłum. G. Waluga, Warszawa 2007.

Constant S., Foxy Ferdinand, 1861-1948. Tsar of Bulgaria, London 1979.

Crampton R.J., Bulgaria, Oxford 2007.

${ }^{17}$ Zob. np. E. Ludendorff, Meine Kriegserinnerungen 1914-1918, Berlin 1919, s. 198. 
Gotlib U., B"lgariâ v meždunarodnata polityka (1914-1915), „Izvestiâ na Instituta za Istoriâ BAN" 1974, 23.

Hartau E., Wilhelm II, tłum. A. Marcinek, Lublin 1995.

Ilčev I., B"lgariâ i Antantata prez p"rvata svetovna vojna, Sofiâ 1990.

Klejn Z., Bułgaria: szkice z dziejów najnowszych, Pułtusk 2005.

Ludwig E., Wilhelm II, tłum. J. Zylberowa, Warszawa 1930.

Nofi A.A., Comparative Divisional Strengths During World War I: East Central European Belligerents and Theaters, [w:] War and Society in East Central Europe, vol. 19: East Central European Society in World War I, eds. B. Király, N.F. Dreisziger, New York 1985.

Nowaczyński A., Wilhelm Imperator 1888-1918, 9 listopada, Katowice 1928.

Oskierko M., Wilhelm II. Awanturniczy Kaiser, Warszawa 1932.

Pisarev Û.A., Velikie deržavy i Balkany nakanune pervoj mirovoj vojny, Moskva 1985.

Pissari M., Bulgarian Crimes against Civilians in Occupied Serbia during the First World War, „Balcanica” 2013, 44.

Podwojski A., Kaiser Wilhelm II, Warszawa 1919.

Schad M., Hohenzollernowie, tłum. M. Urbański, Warszawa 2004.

Statelova E., Gr"nčarov S., Istoriâ na nova B"lgariâ (1878-1944), t. III, Sofiâ 1999.

Todorova C., Istoriâ na v'nešniâ d"žaven d"lg na B"lgariâ (1878-1990 g.), t. I. Dramatično načalo (1878-1918), Sofiâ 2009.

Wereszycki H., Koniec sojuszu trzech cesarzy, t. III, Warszawa 2010 (wyd. II).

\section{ABSTRACT:}

The last German Emperor Wilhelm II Hohenzollern was a figure who aroused and still arouses a significant interest of historians. Being one of the most powerful rulers of his times he has left a strong imprint on world politics. Thanks to his efforts Bulgaria had tied its fate with Germany and joined the First World War. During the summer of 1915 this issue was one of the priorities of the German foreign policy in which he took an active part as a ruler of Germany.

Key words: Wilhelm II Hohenzollern, Germany, Bulgaria, First World War

Dariusz Faszcza - doktor nauk humanistycznych, adiunkt na Wydziale Nauk Politycznych Akademii Humanistycznej im. Aleksandra Gieysztora w Pułtusku. Głównym przedmiotem jego zainteresowań są dzieje wojskowości Polski i Bułgarii w XIX i XX w. jak również problematyka bezpieczeństwa narodowego. Autor siedmiu publikacji książkowych oraz kilkudziesięciu artykułów naukowych i popularnonaukowych poświęconych tej problematyce. Adres mailowy: dariuszfaszcza@o2.pl. 